\title{
Impact of the Jews and Polish-Jewish Relations on the Development of the Banking Sector in Poland
}

\author{
Lech Kurkliński \\ Warsaw School of Economics, Warsaw, Poland
}

\begin{abstract}
The development of the Polish banking sector cannot be separated from the historical, cultural, and religious background. A key role in this area was played by the Jewish minority. Although the discussed subject matter relates to very remote times, due to the durability of cultural determinants, it has a large impact on the present shape of the Polish banking sector. The paper is dedicated mainly to the presentation of interrelations between Christianity and Judaism, the development of the historical Polish-Jewish relations and the role of the Jews in the development of the banking sector on Polish territory. In the light of the deliberations, the author refers to a deeply ingrained distance between a wide group of users of financial services and banks themselves, and to the relations resulting from the domination of foreign capital on the Polish banking market.
\end{abstract}

Keywords: Polish-Jewish relations, banking sector

\section{Introduction}

The relations of banking with the Jews, especially when perceived by the Polish society, but also worldwide, are very strong. In Poland, it is even more interesting, since, as a result of historical events (in particular World War Two, Anti-Semitic Movement in 1968), this minority is basically non-existent. However, this situation confirms importance of cultural aspects, developing over the centuries (Glinka, 2008). Banking belongs to these types of activity where the discussed determinants play an important and much bigger role than in other spheres of economic life. It is a consequence of a number of universal and national reasons: religion and active role of the Catholic Church in this matter until 19th century, historical and national aspects resulting from the turbulent Polish history, emotions related to money possession, and a particular position of banks as public trust institutions. The present attitude towards banking is nothing else but a result of many-century development of attitudes and cultural models, whose transformations are slow, even in spite of so fundamental system transitions and the total transformation of economy in the period of the past 25 years (Kurkliński, 2011). Therefore, when carrying out these analyses, the role of the Jews and Polish-Jewish relations cannot be ignored, even when it comes to very remote times. Moreover, the present times bring one more important aspect of banking activity in Poland - the domination of foreign capital. In cultural terms, it has serious consequences for current operations of banks. At this point, certain analogies appear. This paper is aimed to show these relations by going back to remote history of Poland and showing importance of religious factors.

Lech Kurklinski, Ph.D., assistant professor, Warsaw School of Economics, Warsaw, Poland.

Correspondence concerning this article should be addressed to Lech Kurklinski, Warsaw School of Economics, Madalińskiego street 6/8, 02-513 Warsaw, Poland. E-mail: lech.kurklinski@data.pl. 


\section{Judaism, Christianity, and Banking}

Banking activity appeared in the ancient times, along with the popularization of standard money. It applied, first of all, to the phenomenon of lending and expecting relevant compensation in return, mainly in the form of interest. Nearly simultaneously moral attitude and then religious attitude to these dealings were formed. Already Aristotle was of the opinion that this way of making money is against nature, although his morally negative judgment concerned the situation when a borrower, in particular a minor borrower, was constrained to accept increased interest (Taeusch, 1973). However, the history of economy and the development of banking were (to a certain degree, are until the present day) determined largely by the perception of this phenomenon by great world religions: Christianity, Judaism, Buddhism, Hinduism, Confucianism, and Islam. This attitude was developing similarly, however, its evolution and intensification were different. An example can be the present Islamic banking, banning continuously and strictly charging interest on loans, which has created a different model of banks operation. At least at the beginning, all of the mentioned religions had basically negative attitude towards charging any interest on the lent money, which was diverging only in certain nuances (Kietliński, 2005). The Old Testament does not settle clearly whether the term "usury" applied to each case of demanding compensation for the lent money or it applied to charging excessive and exorbitant interest. The New Testament (Lucas 6.34: 35) clearly recommends the followers to lend money without interest (Wierzbicki, 2011). This attitude will become instilled in the Church and it will take a dozen or so centuries to change. Other mentioned nuances include inter alia - the issue of a person to whom loan would be granted. It is provisionally acceptable to grant interest-bearing loans to "strangers", rather than "ones of us"-The Book of Deuteronomy (Jastrzab, 2013; Taeusch, 1973). This view, initially common for Christianity and Judaism, became established only in the Jewish community. In this way, in Europe, dominated by Christianity, the sphere of money turnover was mainly under the Jewish control (Botticini \& Eckstein, 2012), although that control was not exclusive. Especially in the Middle Ages, lending money was reprehensible and strongly condemned by the Catholic Church. This attitude applied, first of all, to the Christians themselves, but many times also to infidels, including the Jews.

The needs of economic development, imposing the popularization of money-goods relationships, had their repercussion in the interpretation of both religions, with the difference that the Judaism followers were much more flexible in this area and were adapting more quickly to changing conditions. For instance, in Poland, the ban on interest-bearing loans between the Jews (namely between "ones of us") was lifted by the Jewish self-government as early as in 1607. ${ }^{1}$ It contributed to a further development of the credit and financial system this community was dealing with (Siewierski, 2010). Conducted by them, national and international goods turnover and accompanying operations involving bills of exchange were increasing. Bills of exchange were used to pay for goods, however, reliability of their issuers and frequent dishonesty were problematic. As a result, very stringent sanctions were adopted for issuing a worthless bill of exchange. The degree of standardization of this area is reflected also in a decision of the big town Poznan kahal on maximum interest rate in relationships between the Jews, determined at 25\% (Jezierski \& Leszczyńska, 1998).

The Christian world was also noticing the needs to increase money turnover. At the beginning, this process was taking place mainly in the region of central and northern Italy, starting from the 12th century. Demand for

\footnotetext{
${ }^{1}$ Waad Arba Aracot was the superior Jewish authority in Poland (XVI-XVIII century). The Jewish community was enjoying a large autonomy towards state legislative, executive, court, and religious institutions. Along with the crisis of the Polish state, independence of the Jewish community was decreasing and upon the partitions, it was nearly completely lifted.
} 
credit was growing, including demand for investment credit which was involving greater risk and was accompanied by an expectation of compensation for lender. First quasi-banking institutions began to emerge. This situation was hardy acceptable for the Catholics that was strongly reprimanding usurers. However, with the passage of time, the church authorities changed gradually their attitude towards progressing economic transformations, especially in view of growing importance of financial transactions. In spite of the above, in official terms, the Catholic Church lifted the ban on usury no sooner than 1830 (Kracik, 2004).

With regard to reformatory movements, the attitude towards paid money lending was similar as of the Catholic Church. Martin Luther was strongly reprimanding those dealings. Anglican theologians were taking similar stands on the issue. An exception was John Calvin who reconciled religion and the world of money, contributing to the development of the Protestant mentality, which appreciates values, such as work and prosperity (Kracik, 2004). The emerging Protestant culture along with strongly developing money-goods economy was forming a good basis for developing banking activity. It was taking place largely beyond Jewish environments, since as a result of displacements, the Jews were not an important social group in Western European countries.

Regardless of the position of the Catholic Church, also secular authorities of most countries were trying to regulate the issue of granting loans. In Poland, starting from 1775, the principles of charging interest were standardized; they were applicable also for the Jews. Along with the partitions, regulations of the partitioners were implemented on Polish territory, providing for restrictions in interest. The second half of the 19th century brought about an unquestionable liberalization of regulations.

The discussion and legal attempts of eliminating or restricting usury re-emerged in public life in the Second Republic of Poland (1918-1939), inclusive of penalization of this phenomenon in the criminal code. Another development of this subject matter was its strong comeback in the recent history of Poland, in the form of a debate and final enactment in 2005 of an act banning excessive interest (Wierzbicki, 2011), remaining in force until the present day.

\section{History of Polish-Jewish Relations}

The Jewish settlement on Polish territory dates back to the early 10th century; it intensified over the period of crusades (1096-1270), which was a consequence of increasing hostility and even hatred towards the Jews in Western European cities and their frequent displacements. They were often seeking shelter in Poland, relatively highly tolerant ${ }^{2}$ at those times (Weinryb, 1973; Weintraub, 1971). The foundations for formal position of the Jews in Poland were provided by The Statute of Kalisz issued by the Duke Boleslaus the Pious in 1264. It granted that, inter alia, Jewish courts guaranteed personal liberty and safety of the Jews, including, first of all, freedom of religion, travelling, and trade. Its provisions were confirmed by subsequent kings. However, the mere fact of the necessity to ensure freedoms for the Jewish community proves not fully equal position of this nationality representatives; an example may be a part of The Warta Statute issued by the King Władysław II Jagiełło, which restricted lending activity of the Jews. On the other hand, the Jews often enjoyed a privileged position (for instance, rights to operate taverns and inns and rights to run retail of alcoholic drinks). In the whole, living conditions were relatively good, which contributed to the boom of the Jewish population in Poland from approximate 10 thousand in 1340 to more than 750 thousand in 1772 (Pogonowski, 1998). Hence,

\footnotetext{
${ }^{2}$ In the later times, local strongly anti-Jews tendencies were emerging, inter alia, some towns were receiving rights to ban the Jews from residing in them-the privilege De non tolerandis Judeas.
} 
in the late 18th century, the Jewish population living on the territory of Poland accounted for approximate half of the Jewish population worldwide (Siewierski, 2010).

The period of prosperity of the Polish state implied also good times for the Jews. However, at the time of emergence of serious social, economic, or political problems, they often had negative repercussions for the Jewish community, for instance, the Chmielnicki uprising (1648-1657) caused slaughter of approximate 100 thousand Jews and the difficult times of the Swedish Deluge (1655-1660) caused mass attacks and persecutions of the Jews (Attali, 2002). This tendency is even more noticeable in the period of the declining independency of of Poland (18th century). In 1764, the Jewish parliament Waad was dissolved. In 1768, pogroms took place in following towns: Krakow, Poznań, Lvov, Vilnius, and Brest (more than 10 thousand victims) (Attali, 2002), whereas peasant revolts termed koliszczyzna (1768) in the eastern borderland of Poland caused another 50,000 Jewish victims. The problem of safety and living conditions of the Jews became so urgent that it was deliberated on by the Great Parliament (1788-1792) (Petelewicz, 2009). It concludes that the successive partitions of Poland put a stop to the era of relative tolerance and brought increasing and solidifying hostility in Polish-Jewish relations, stirred up more or less by the partitioners (Russia, Austria, and Prussia).

The partitioners were executing discriminatory policy against the Jews. No sooner than the second half of the 19th century was this attitude mitigated, mainly in Galicia (Austria) and partially in Russia. The number of the Jews on Polish territory kept increasing; in the late 19th century, it reached approximate 2.2 million, and in the early 20th century, as a result of the Jewish immigration from the interior of Russia, it grew by another 600 thousand (Petelewicz, 2009). The assimilation with the Polish society was running very slowly and mutual antagonisms were intensifying. Under these socio-economic and political conditions, due to administrative and legal actions, the attitude of the Catholic Church and the Jewish society tendency to cultivate cultural, language and religious distinctness, the Jews were largely isolated from the rest of the society. The Jews were and remained "strangers".

At the brink of the recovered independence of Poland, after World War One, the Jewish minority accounted for $10 \%$ of the Polish population. Its status was guaranteed by the Minority Treaty (equal civic rights and obligations, self-government, and religious autonomy, right to speak own language, and etc.). However, strong anti-Jewish tendencies in the society were preserved. They were upheld in the whole interwar period (for instance, boycotts of Jewish stores in the years 1929-1935); they were intensifying and supported with a certain form of state anti-Semitism (ghetto desks at universities). The Great Depression and anti-Jewish attitudes were reflected in worsening economic situation of the Jews. Nevertheless, in 1939, the Jewish population grew to 3.3 million (Petelewicz, 2009).

The outbreak of World War Two and the German occupation implied the extermination of the Polish Jews. Criminal actions of the Nazis resulted in deprivation of property, slave exploitation, and then physical extermination of nearly whole Jewish society. Under unimaginable occupation conditions, the attitude of the Poles towards the Holocaust was mostly a consequence of intimidation and terror. Certain Poles were helping the Jewish in spite of the danger, but certain were Gestapo informers, thieves, and blackmailers who wanted to make a fortune at expense of the Jews. The final balance is not clear. After the war, in Poland approximate 80-100 thousand Jews survived plus 140 thousand were repatriated from the Polish territory annexed by the Soviet Union. In spite of traumatic experiences of both nations during the occupation, the Polish society was not friendly towards the Jews. This attitude was partially a consequence of a relatively active role of the Jews in 
the imposed pro-Soviet authority and of anti-Semitism that had solidified over the years (Jastrzab, 2013). The most rough event that exemplifies these attitudes was the Kielce Pogrom in 1946. Under these circumstances, until 1950, more than 130 thousand Jews emigrated from Poland. Next emigration waves were recorded after 1956, when the emigration policy was loosened, after the March anti-Semitic events in 1968. Presently, Poland has 12-15 Jewish inhabitants (Petelewicz, 2009), almost invisible as compared to the nationally monolithic Polish society.

\section{Role of the JEWS in the Development of the Polish Banking}

After considering the religious determinants of Judaism and Christianity and confronting them with the history of Polish-Jewish relations, the development of the Polish banking and the role played in it by the Jewish minority representatives are interesting.

Thanks to the religious and cultural distinctness of the Jews in relations to the Christians, they basically took over not only retail banking (the term would be used today), but also ducal and royal finance. It was giving them a kind of privileged position and protection granted to "the treasury servants": a reason for intensified indignation of the catholic clergy, often inciting open hatred, which was gaining the ear mainly of lower social strata. In spite of the above, for instance, the King Casimir III the Great was appreciating the role of the Jews in Polish economy (many Jews were tax collectors). The religious and customary differences were preserving their cultural distinctness, solidifying the status of "strangers". This situation was reinforced by usurious activity run by the Jews, often at a presently shocking level. As a result, representatives of this nationality were falling victims to many assaults and robberies. The reliability of financial transactions conducted by the Jews was reinforced by the principle of several liability of Jewish communes (kahals) for their members' obligations. Therefore, investing money through the Jews was not that risky, and kahals were playing the role of quasi-banks; they were conducting financial transactions involving entrusted funds and paying out annual interest of $7 \%$ to $10 \%$ (Kietliński, 2005).

Taking into account the whole of socio-economic determinants, basically the lending-banking activity wasn't developed in the Polish society, apart from the activity of the Jews. However, there were the examples of activity of Christian bankers, although some of them were foreigners. A more active role of non-Jewish banking houses emerged no sooner than the 18th century and was also largely determined by religious considerations. Apart from the Jews, the banking profession was dominated by the Protestants. In 1793, the first Polish banking crisis broke out. Then Polish banking turned into ruin (seven major banking houses went bankrupt); only few smaller ones survived the crisis. This event preceded the third partition of Poland and the loss of independence. The level of the development of banking on Polish territory regained a comparable condition no sooner than the mid-19th century (Morawski, 1998).

After the Napoleonic era, only few initiatives of founding banks were initiated. In 1825, Towarzystwo Kredytowe Ziemskie (Land Credit Society) and Bank Polski (Bank of Poland) - a state credit institution, were founded. With regard to private banks, they were treated very distrustfully on the territory under Russian rule until the 1870s. In Galicia, several dozens of small banking houses (mainly Jewish) were operating and a bigger institution of this type was founded no sooner than 1841: Galicyjski Stanowy Instytut Kredytowy (Galician State Credit Institute) in Lvov. Polish banking was the weakest in Prussia, where first banks were founded in the 1860s (Morawski, 1998). They were to be replaced by private lending activity, mostly usury, dealt with by the Jews, everywhere where official banking entities were missing. 
The socio-economic transformations, related to the abolition of corvee labor, expansion of towns and industry, and liberalization of the regulations on loan interest, contributed to a stronger development of banking. Then, the financial entities can be divided into private banking houses, joint-stock banks, and credit societies. The first group operated already in the pre-partition period, but it was not numerous. The second group, also weak, did not have expanded branches. In both cases, the leading role was played by Jewish bankers, for instance, Kronenberg, the initiator of the biggest institution-Bank Handlowy in Warsaw. The situation was not differing from similar tendencies in a number of European countries, especially in Germany and in the Austro Hungarian Empire (Schijf, 2002).

Minor clients-borrowers - were served by local credit unions. These were mostly cooperatives following the models of Schulze or Raiffeisen, and savings unions in all three partitions (Leszczyńska \& Lisiecka, 2004). Nevertheless, neither banks, nor other credit entities were able to rule out broadly-expanded private lending activity, run often on usurious terms, mainly on the part of the Jewish community representatives (Kracik, 2004).

Under these circumstances, a common cultural attitude towards banking was developing, with a very clear negative connotation, overlapped additionally with growing anti-Semitism. Dealing with finance was a task assigned to the Jewish community, therefore, this sphere of economic activity was assessed largely through the prism of attitude towards the Judaism followers.

A summary of the period before World War One may be the list of 10 biggest Polish banks with respective share of Jewish capital (Table 1).

Table 1

List of Polish banks at the Brink of World War One-Jewish Capital

\begin{tabular}{|l|l|l|l|}
\hline Bank name & Year of founding & Seat & Jewish capital \\
\hline 1. Bank Handlowy w Warszawie SA & 1870 & Warsaw & YES \\
\hline 2. Wileński Bank Ziemski SA 1872 & 1872 & Vilnius & YES \\
\hline 3. Bank Dyskontowy Warszawski SA & 1871 & Warsaw & YES \\
\hline 4. Bank Handlowy w Lodzi SA & 1872 & Lódź & YES \\
\hline 5. Gal. Akcyjny Bank Hipoteczny SA & 1867 & Lvov & NO \\
\hline 6. Bank Krajowy & 1883 & Lvov & NO \\
\hline 7. Bank Zachodni SA & 1913 & Warsaw & YES \\
\hline 8. Łódzki Bank Kupiecki SA & 1897 & Lódź & YES \\
\hline 9. Bank Handlowy W. Landau SA & 1914 & Warsaw & YES \\
\hline 10. Bank Przemysłowy dla Galicji SA & 1910 & Lvov & YES \\
\hline
\end{tabular}

Source: Morawski (2002).

A clear domination of the Jewish community in banking activity can be seen, both in terms of institutions (banks) and granting private loans.

After the recovery of independence in 1918, the situation started changing slowly. Relatively quickly enacted legal acts against usury prove social importance of this phenomenon and indirectly the perception of banking. It should be examined together with very strong Anti-Semitic Movement and related attitudes of the society. Trust in state banks was increasing; their position was growing, which was visible in particular during the Great Depression. The bankruptcy of several Polish private banks and the collapse of big institutions abroad stirred panic; clients started nervously transferring money to state banks. The post-depression picture is 
illustrated by the following data; in 1926, private savings-credit institutions had $43 \%$ of total deposits; in 1936 this level fell below $20 \%$. As a result of reformatory processes, large banks were nationalized, directly or indirectly; it applied, among others, to Bank Handlowy w Warszawie S.A.. Control of entities remaining in private hands was taken over largely by foreign capital (Landau, 2007). These tendencies could be noticed also among Jewish banks. From among bigger banks, only Dom Bankowy D. M. Szereszowski preserved its image of an institution perceived as belonging to and serving the Judaism followers (for instance, nearly all Jewish organizations were depositing their money in this bank).

During World War Two, occupation and a new soviet post-war system basically end the history of Jewish banking in Poland.

\section{Conclusions}

The history of banking in Poland is connected inseparably with the Jews and Polish-Jewish relations. Its tracing enables to understand better contemporary Polish banking, in particular the attitude of the society to this type of economic activity. It is beyond doubt that the distance separating the Polish population from the Judaism followers over the centuries was reflected in the attitude to banking (quasi-banking) institutions, including main activity — granting loans (credits). The above cultural determinants, though very remote in time, are ingrained in social awareness. Banks are perceived as entities with a special status, which results only partially from the position of a public trust institution. Attention is paid to their privilege and formal/informal power (domination) over a regular client. This phenomenon is widely spread worldwide, but noted especially in Poland. Additionally, it must be introduced an element of the dominance of foreign capital in the Polish banking sector. This aspect reinforces the abovementioned distance, which can be exemplified, for instance, by the semantic expression "strange capital" used in relation to foreign investors in Poland. The thesis can be confirmed that this "strangeness" reflects to a certain degree the cultural distance present over nearly 1,000 years between the Polish and Jewish communities. Therefore banks with foreign capital, in particular their owners, should pay special attention to cultural aspects when running activity in Poland. The manifestations of ethnocentrism can be observed in many cases on the part of international corporate groups are not favorable for success on the Polish market, which has been experienced by quite many banks.

\section{References}

Attali, J. (2002). Les Juifs, le monde et l'argent (The Jews, the world and the money). Paris: Librairie Arthème Fayard.

Botticini, M., \& Eckstein, Z. (2012). Religious norms, human capital, and money lending in Jewish European history. Retrieved from http://www1.idc.ac.il/Faculty/ Eckstein/pdf/Botticini\%20 and\%20Eckstein\%20Handbook\%20Chapter.pdf

Glinka, B. (2008). Kulturowe uwarunkowania przedsiębiorczości w Polsce (The cultural context of the entrepreneurship in Poland). Warszawa: PWE.

Jastrząb, M. (2013). Żydowscy waluciarze przed Komisją Specjalną, czyli o trwałości stereotypów kulturowych (The Jewish black market money changers before the special commission - the durability of cultural stereotypes). Proceedings from conference The Role of the Jews in the Economic Development on Polish Territory.

Jezierski, A., \& Leszczyńska, C. (1998). Historia gospodarcza Polski. Wydawnictwo (The economic history of Poland). Warszawa: Key Text.

Kietliński, K. (2005). Religijne, historyczne i kulturowe uwarunkowania etyki biznesu (The religious, historic and cultural circumstances of business ethics). In K. Kietliński, V. M. Reyesai, \& T. Oleksyn (Eds.), Etyka biznesu (The business ethics). Krakow: Oficyna Ekonomiczna.

Kracik, J. (2004). Kredyt i lichwa jako zjawiska społeczne (The lending and usury as the social phenomena). Proceedings from 17th General Congress of Polish Historians. 
Kurkliński, L. (2011). Wyzwania rozwojowe bankowości a jej uwarunkowania historyczno-kulturowe w Polsce (Banking development challenges - historical and cultural circumstances in Poland). In A. Gospodarowicz (Ed.), Finanse-nowe wyzwania teorii i praktyki. Bankowość (Finance—new challenges of theory and practice. Banking). Wrocław: Wrocław University of Economics.

Landau, Z. (2007). Czy doświadczenia bankowości Polski międzywojennej mogą być przydatne dla polskiej bankowości współczesnej (Can the interwar Polish banking experience can be useful for Polish contemporary banking). Acta Oeconomica Pragensia, 15, 282-287.

Leszczyńska, C., Lisiecka Ł. (2004). Od banku pobożnego do banków państwowych i prywatnych. Banki w Polsce, ich rola ekonomiczna, społeczna i kulturowa (From pious banks to public and private banks. Banks in Poland, their economic, social and cultural role). Proceedings from 17th General Congress of Polish Historians.

Morawski, W. (1998). Słownik historyczny bankowości polskiej do 1939 roku (The historic dictionary for Polish banking before 1939). Warsaw: Muza.

Morawski, W. (2002). Zarys powszechnej historii pieniqdza i bankowości. Wydawnictwo (The outline of the general history of money and banking). Warszawa: TRIO.

Petelewicz, J. K. (2009). Dzieje Żydów w Polsce (The history of Jews in Poland). Retrieved from: http://www.zydziwpolsce.edu.pl/biblioteka/czytelnia/pr_h003.pdf

Pogonowski, I. C. (1998). Jews in Poland. A documentary history. New York: Hippocrene Books.

Schijf, H. (2002). International Jewish bankers between 1850 and 1914: An example of internationalization along ethnic lines. Proceedings from Economic History Congress XIII, Buenos Aires.

Siewierski, J. (2010). Idea wielokulturowości. Tradycja Rzeczypospolitej i doświadczenia obecne (The idea of multiculturalism. The tradition of the commonwealth of Poland and Lithuania. Present experience). Warszawa: Oficyna Wydawnicza SGH.

Taeusch, C. E. (1973). The concept of "usury" the history of an idea. Journal of the History of Ideas, 3(3), 291-318.

Weinryb, D. B. (1973). The Jews of Poland: A social and economic history of the Jewish community in Poland from 1100 to 1800. Philadelphia: Jewish Publication Society of America.

Weintraub, W. I. (1971). Tolerance and Intolerance in old Poland. Canadian Slavic Papers, 13, 21-43.

Wierzbicki, J. (2011). Ochrona konsumenta przed nadmiernymi odsetkami. Skuteczność rozwiązań antylichwiarskich. "Praktyczna Teoria" (Consumer protection against excessive interest. The effectiveness of no usurious solutions). Retrieved from: http://www.praktycznateoria.pl/ochrona-konsumenta/ 